\title{
Predation and ingestion of a viviparous lizard (Zootoca vivipara) by the common wall lizard (Podarcis muralis) in England
}

\author{
OLIVER THOMAS ${ }^{*}$, STEVEN J. R. ALLAIN² \& PAUL SAGAR ${ }^{3}$
}

${ }^{1}$ Department of Biosciences, Swansea University, Swansea, SA2 8PP

${ }^{2}$ Cambridgeshire \& Peterborough Amphibian and Reptile Group

${ }^{3}$ Department of Political Economy, King's College London, London, WC2B 4BG

*Corresponding author e-mail: olliethomas444@gmail.com

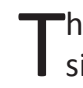
he common wall lizard (Podarcis muralis) is a small-medium sized lacertid that attains a snout to vent length (SVL) of about $7.5 \mathrm{~cm}$ and varies considerably in colour or pattern. Its diet includes a wide range of invertebrates and small lizards including its own young (Speybroeck et al., 2016). The species ranges widely in continental Europe but has been introduced into the Netherlands, Germany and Britain (Speybroeck et al., 2016). Common wall lizards are thought to impact the native viviparous lizard (Zootoca vivipara) through competition and displacement (Mole, 2010) but this has yet to be quantified.

The viviparous lizard is a particularly cold tolerant species occupying a wide range of habitats across an expansive range that extends from Ireland to Japan but absent from much of southern Europe (Speybroeck et al., 2016). They too vary in colour but often tend to be brown, with females possessing a dorsal stripe and the males a brightly coloured belly (Beebee \& Griffiths, 2000). Viviparous lizards are the smallest and most widespread lizard species in the British Isles but their populations are declining for a variety of reasons (Beebee \& Griffiths, 2000). They prefer open habitats that are undisturbed and have exposure to the sun such as railway embankments, cliffs and heathland (Inns, 2011). This can lead to them coming into direct contact with $P$. muralis.

The common wall lizard has numerous established populations in England (Quayle \& Noble, 2000) and Wales. One of the most well-studied is at Boscombe Cliffs in Dorset (SW England) (Gleed-Owen, 2004; Mole, 2010). Using genetic analysis this population of $P$. muralis was found to originate from either France or Italy (Michaelides et al., 2015), whereas the nearby Seacombe population, which happens to be closest to the sighting described here, was found to be of Venetian origin (Michaelides et al., 2015).

At $15: 19 \mathrm{~h}$ on 13 May 2020 an adult $P$. muralis was observed by PS capturing and ingesting an adult $Z$. vivipara among boulders and foliage in Winspit Quarry, Dorset (GPS: $50^{\circ} 35^{\prime} 05.5^{\prime \prime} \mathrm{N} 2^{\circ} 01^{\prime} 59.1^{\prime \prime} \mathrm{W}$ ). The $Z$. vivipara was grasped just behind the front legs (Fig. 1) before the whole lizard was swallowed head-first in its entirety. The process lasted approximately 5 minutes, with $P$. muralis ingesting $Z$. vivipara in stages with pauses of about 30 seconds at a time, returning to a rock in direct sunlight to complete ingestion after having been briefly disturbed by a passer-by.

To our knowledge this is the first observation of $P$. muralis feeding on Z. vivipara although this behaviour is consistent with the known habit of this species to eat small lizards. It would seem that $P$. muralis is not only a potential

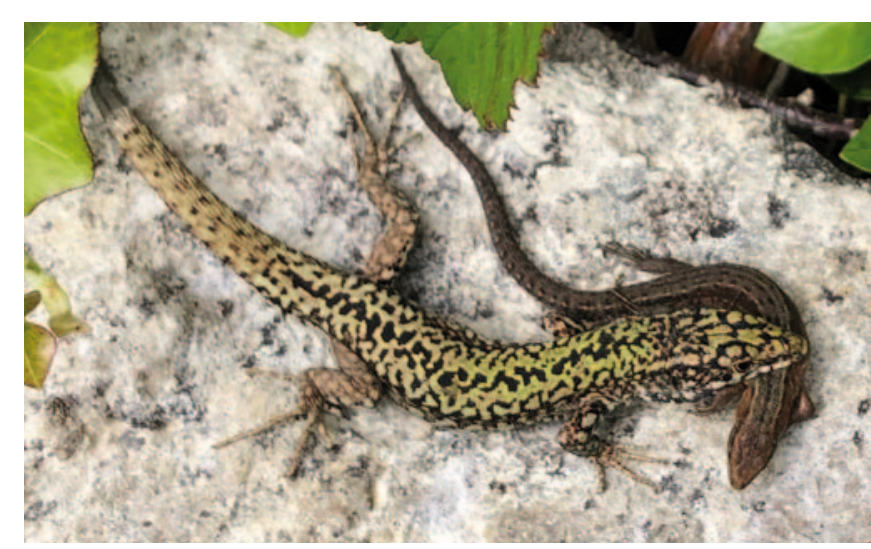

Figure 1. An adult male common wall lizard ( $P$. muralis) holding a viviparous lizard (Z. vivipara) in its mouth shortly before consuming the smaller lizard whole

competitor of the viviparous lizard but it is also a predator. Besides competition and predation common wall lizards may potentially threaten viviparous lizard populations through transfer of pathogens or parasites although this aspect has still to be investigated.

\section{REFERENCES}

Beebee, T. J. C. \& Griffiths, R. A. (2000). Amphibians and Reptiles: A Natural History of the British Herpetofauna. London, HarperCollins. 270 pp.

Gleed-Owen, C.P. (2004). Green lizards and wall lizards on Bournemouth cliffs. Herpetological Bulletin 88: 3-7.

Michaelides, S. N., While, G. M., Zajac, N. \& Uller, T. (2015). Widespread primary, but geographically restricted secondary, human introductions of wall lizards, Podarcis muralis. Molecular Ecology 24: 2702-2714.

Mole, S. R. C. (2010). Changes in relative abundance of the western green lizard Lacerta bilineata and the common wall lizard Podarcis muralis introduced onto Boscombe Cliffs, Dorset, UK. Herpetological Bulletin 114: 24-29.

Quayle, A. \& Noble, M. (2000). The wall lizard in England. British Wildlife 12: 99-106.

Speybroeck, J., Beukema, W., Bok, B. \& Van Der Voort, J. (2016). Field Guide to the Amphibians and Reptiles of Britain and Europe. London, Bloomsbury Publishing. 432 pp.

Accepted: 24 May 2020 